\title{
DISTRIBUSI DAN KANDUNGAN KARBON PADA LAMUN (Enhalus acoroides) DI PULAU KEMUJAN TAMAN NASIONAL KARIMUNJAWA BERDASARKAN CITRA SATELIT
}

\author{
Distribution and Carbon biomass of Seagrass (Enhalus acoroides) in Kemujan Island Karimunjawa National \\ Park Based on Satellite
}

\author{
Alfian Zulfikar, Agus Hartoko, Boedi Hendrarto
}

Program Studi Manajemen Sumberdaya Perairan, Departemen Sumberdaya Akuatik

Fakultas Perikanan dan Ilmu Kelautan, Universitas Diponegoro

J1. Prof. Soedarto, SH, Tembalang, Semarang, Jawa Tengah - 50275, Telp/Fax. +6224 7474698

Email : alfian_zulfikar20@yahoo.co.id

\begin{abstract}
ABSTRAK
Padang lamun merupakan salah satu ekosistem yang sangat penting di wilayah pesisir. Salah satu fungsi dari lamun yaitu sebagai penyerap karbon. Adanya berbagai kegiatan yang dilakukan oleh masyarakat di Pulau Kemujan dikhawatirkan dapat mengganggu fungsi lamun tersebut. Lamun tersebar sepanjang pantai sebelah barat Pulau Kemujan sehingga penggunaan teknologi penginderaan jauh diharapkan dapat membantu dalam penelitian ini. Tujuan dari penelitian ini yaitu mengetahui pengaruh dari kegiatan manusia terhadap fungsi lamun sebagai penyerap karbon dengan cara membangun pemodelan algoritma berdasarkan citra satelit Aster. Adapun pengambilan sampel dilakukan secara purposive sampling. Analisis kandungan karbon pada lamun menggunakan metode Walkley \& Black. Hasil kandungan karbon tertinggi terdapat pada rhizome berkisar antara $12,498-55.967 \mathrm{~g} \mathrm{C} / \mathrm{m}^{2}$ sedangkan akar berkisar antara $0,475-27,147 \mathrm{~g} \mathrm{C} / \mathrm{m}^{2}$ dan daun berkisar antara 4,374 $30,346 \mathrm{~g} \mathrm{C} / \mathrm{m}^{2}$. Hasil penelitian menyimpulkan bahwa distribusi biomassa dan kandungan karbon lamun (Enhalus acoroides) di Pulau Kemujan Taman Nasional Karimunjawa menyebar tidak merata, hal tersebut menunjukkan adanya pengaruh dari kegiatan manusia terhadap fungsi lamun sebagai penyerap karbon.
\end{abstract}

Kata kunci: Lamun, Kandungan karbon, Pulau Kemujan Taman Nasional Karimunjawa

\section{ABSTRACT}

Seagrass beds are one of the very important ecosystems in coastal areas. One function of seagrass is carbon sinks. Activities in Kemujan island was suspected to interfere function of seagrass. Seagrass was found along the west of Kemujan island, so that using of remote sensing technology can help in this research. The aimed of this research was to determine the influence of human activities on the functioning of seagrass as a carbon sink by building modeling algorithm based on Aster satellite. Sampling teqhnique was purposive sampling. Analysis of carbon biomass in seagrass using Walkley \& Black method. The results of the highest carbon biomass was found in the rhizome ranged from 12.498 to $55,967 \mathrm{~g} \mathrm{C} / \mathrm{m}^{2}$ while the roots ranged from 0.475 to $27.147 \mathrm{~g} \mathrm{C} / \mathrm{m}^{2}$ and leaves ranged from 4.374 to $30.346 \mathrm{~g} \mathrm{C} / \mathrm{m}^{2}$. This research, concluded that the distribution of biomass and carbon biomass of seagrass (Enhalus acoroides) in Kemujan Island Karimunjawa National Park spread unevenly, it showed the influence of human activities on seagrass function as carbon sinks.

Keywords: Seagrass, carbon biomass, Kemujan Island Karimunjawa National Park.

\section{PENDAHULUAN}

Pulau Kemujan, salah satu pulau di Taman Nasional Karimunjawa merupakan pulau yang memiliki daerah yang ditumbuhi oleh padang lamun, diantaranya kawasan terusan kemujan, Legon Besar, Legon Tengah, Legon Pinggir, Merican, Telaga, dan sepanjang pantai dari utara hingga selatan sebelah barat Pulau Kemujan. Pulau Kemujan juga dijadikan daerah pemukiman oleh penduduk, seperti halnya Pulau Karimunjawa. Aktifitas yang dilakukan oleh penduduk di pulau kemujan tersebut memiliki potensi menimbulkan kerusakan terhadap ekosistem padang lamun. Kemampuan lamun dalam menyerap karbon dapat terganggu karena adanya berbagai kegiatan yang dilakukan oleh penduduk sekitar maupun para turis yang datang berwisata seperti pencemaran lingkungan, penggunakan alat tangkap tidak ramah lingkungan, pembuangan sampah, jangkar kapal nelayan, alih fungsi lahan, dan sebagainya.

Lamun yang diukur kandungan karbonnya adalah lamun jenis Enhalus acoroides. Lamun Enhalus acoroides salah satu jenis lamun yang hidup dan persebarannya ada di perairan Taman Nasional Karimunjawa khususnya di pantai sebelah barat Pulau Kemujan. Hal ini sesuai dengan hasil dari penelitian yang dilakukan oleh Wicaksono et al., (2012), lamun yang ditemukan di perairan Taman Nasional Karimunjawa terdapat 8

\footnotetext{
${ }^{\circ}$ Copyright by Management of Aquatic Resources (MAQUARES)
} 
(delapan) jenis. Adapun jenis-jenis lamun antara lain: Cymodocea rotundata, Cymodocea serrulata, Thalassia hemprichii, Enhalus acoroides, Halodule pinifolia, Halodule uninervis, Halophila ovalis dan Syringodium isoetifolium. Khusus lamun jenis Enhalus acoroides bisa di temukan di Pulau Kemujan. Di perairan Pulau Kemujan terdapat 9 (sembilan ) jenis lamun salah satunya jenis Enhalus acoroides. Padang lamun tersebar di seluruh perairan Taman Nasional Karimunjawa sampai dengan kedalaman 25 meter (BTNKJ, 2012).

Lamun merupakan salah satu ekosistem yang sangat penting di wilayah pesisir. Berbagai jenis ikan menjadikan daerah padang lamun sebagai daerah mencari makan (feeding ground), pengasuhan larva (nursery ground), tempat memijah (spawning ground), sebagai stabilitas dan penahanan sedimen, mengurangi dan memperlambat pergerakan gelombang, sebagai tempat terjadinya siklus nutrien (Kikuchi dan Peres 1997 dalam Wicaksono et al., 2012; Philips dan Menez 1988 dalam Graha, 2015) dan fungsinya sebagai penyerap karbon di lautan atau dikenal dengan istilah blue carbon dan digunakan untuk proses fotosintesis (Kawaroe, 2009 dalam Graha, 2015).

Padang lamun (Enhalus acoroides) tersebar di sebelah barat Pulau Kemujan. Sementara penggunaan teknologi penginderaan jauh belum banyak digunakan dalam penelitian sebelumnya dilokasi tersebut. Teknologi penginderaan jauh digunakan karena dirasa sangat membantu dalam penelitian ini mengingat luasnya daerah sebaran lamun itu sendiri. Kelebihan penggunaan teknologi ini adalah mampu merekam area yang luas dan sulit dijangkau sekalipun serta secara temporal merekam objek atau fenomena pada suatu wilayah (Chen et al., 2016). Degradasi luasan ekosistem padang lamun dari tahun ke tahun semakin meningkat yang diakibatkan oleh faktor alam maupun manusia itu sendiri. Hal sama ditunjukkan dari hasil penelitian Sakaruddin (2011), bahwa pengurangan luasan lamun dari tahun ke tahun semakin bertambah dalam kurun waktu sepuluh tahun terakhir mulai tahun 1990 - 2010 di Pulau Panjang Teluk Banten.

\section{MATERI DAN METODE PENELITIAN}

Materi yang digunakan dalam penelitian ini adalah lamun jenis Enhalus acoroides, titik koordinat yang didapat dari plotting GPS dan citra satelit ASTER. Variabel yang diamati kerapatan, penutupan, biomassa, dan kandungan karbon pada lamun. Adapun pengambilan sampel dilakukan secara purposive sampling. Lokasi sampling penelitian ditentukan berdasarkan atas ada tidaknya padang lamun di daerah tersebut, sedangkan penentuan jumlah kuadran yang diambil sebesar 30\% dari luasan padang lamun yang dijadikan titik sampling dan pengambilan sampel lamun sebanyak 10\% - 30\% dari jumlah kuadran yang dihitung. Pengambilan sampel lamun dilakukan dengan cara pemanenan (Destructive sampling) secara in situ, dilaksanakan dengan memanen seluruh bagian tumbuhan termasuk akarnya, mengeringkannya dan menimbang berat biomassanya (Sutaryo, 2009). Pengamatan jenis dan penutupan lamun berdasarkan panduan dari Guidelines For The Rapid Assessment Of Seagrass Habitats In The Western Pacific (McKenzie, 2003).

\section{Perhitungan kerapatan lamun, biomassa, dan kandungan karbon pada lamun}

a. Kerapatan lamun

Nilai kerapatan dapat menentukan nilai kelimpahan. Data yang sudah didapat kemudian dihitung dengan rumus sebagai berikut (Brower et al., 1989):

$$
\begin{array}{lll} 
& \multicolumn{1}{c}{\boldsymbol{D}=\frac{\mathbf{N i}}{\boldsymbol{A}}} \\
\text { Keterangan : } & \mathrm{Di} & \text { = Jumlah individu (tegakan) ke-i persatuan luas } \\
& \mathrm{Ni} & \text { = Jumlah individu (tegakan) ke-I dalam transek kuadrat } \\
\mathrm{A} & \text { = Luas transek kuadrat }
\end{array}
$$

b. Biomassa lamun

Prosedur pengukuran biomassa lamun dilakukan dengan cara pemanenan (Destructive sampling) secara in situ, dilaksanakan dengan memanen seluruh bagian tumbuhan termasuk akarnya, mengeringkannya dan menimbang berat biomassanya. Menurut Mellor (1991) dalam Sarah et al., (2015) rumus perhitungan biomassa melalui berat kering adalah sebagai berikut:

Keterangan : $\quad \mathrm{B}=$ Biomassa $\left(\mathrm{g} / \mathrm{m}^{2}\right)$

$$
\boldsymbol{B}=\boldsymbol{W} \cdot \boldsymbol{A}
$$

$\mathrm{W}=$ Berat kering lamun setelah pengeringan dengan suhu $60^{\circ} \mathrm{C}$ selama $48 \mathrm{jam}$ $\mathrm{A}=$ Tutupan persatuan luas $\left(\mathrm{m}^{2}\right)$

c. Kandungan karbon

Perhitungan kandungan karbon (\%) pada lamun bagian atas meliputi daun dan pelepah daun serta bagian bawah meliputi akar dan rhizome. Perhitungan nilai kandungan karbon lamun perjaringan (daun, rhizome, dan akar) dianalisis dengan menggunakan metode Walkley dan Black (Schumacher, 2002 dalam Kiswara, 2010; Sulaeman et al, 2005 dalam Graha 2015). Metode Walkley dan Black dilakukan dengan prosedur sebagai berikut:

Sebanyak 0,5 gram sampel kering ditimbang lalu dimasukkan kedalam labu ukur 100 ml, kemudian ditambah larutan $\mathrm{K}_{2} \mathrm{Cr}_{2} \mathrm{O}_{7} 1 \mathrm{~N}$ sebanyak $5 \mathrm{ml}$ dan larutan $\mathrm{H}_{2} \mathrm{SO}_{4}$ pekat sebanyak 7,5 ml lalu dikocok, setelah itu diamkan selama 30 menit. Larutan kemudian diencerkan dengan air bebas ion, dibiarkan dingin dan diimpitkan.

(C) Copyright by Management of Aquatic Resources (MAQUARES) 
Keesokan harinya diukur absorbansi larutan jernih dengan spektrofotometer pada panjang gelombang $561 \mathrm{~nm}$. Sebagai pembanding dibuat standar 0 sampai 250 ppm, dengan memipet 0 dan 5 ml larutan standar 5000 ppm kedalam labu ukur $100 \mathrm{ml}$ dengan perlakuan yang sama dengan pengerjaan contoh.

Kandungan karbon jaringan lamun dengan metode Walkley dan Black adalah sebagai berikut:

Kadar karbon organik $(\%)=$ ppm kurva $\mathrm{x} \mathrm{ml} \mathrm{ekstrak} 1000 \mathrm{ml}^{-1} \mathrm{x} 100 / \mathrm{mg}$ contoh $\mathrm{x} \mathrm{fk}$

$$
\begin{aligned}
& =\text { ppm kurva } \times 100 / 1000 \times 100 / 500 \times \mathrm{fk} \\
& =\text { ppm kurva } \times 0,02 \times \mathrm{ffp} \times \mathrm{fk}
\end{aligned}
$$

Keterangan:

ppm kurva

$$
\begin{array}{ll}
\mathrm{fp} & =\text { faktor pengenceran (bila ada) } \\
\mathrm{fk} & =\text { faktor koreksi kadar air }=100 /(100-\% \text { kadar air })
\end{array}
$$

Untuk menghitung biomas dalam satuan gram karbon per meter persegi $\left(\mathrm{g} \mathrm{C}^{2} \mathrm{~m}^{2}\right)$ mengikuti BARRÓN et al., (2004) dalam Kiswara, (2010), yang menghitung bobot karbon biomas per $\mathrm{m}^{2}\left(\mathrm{gC} / \mathrm{m}^{2}\right)$ bagian tanaman lamun dari g.bobot kering $\left(\mathrm{gBK} / \mathrm{m}^{2}\right)$ yang dikonversi ke mol $\mathrm{C}$ dengan persentase kandungan karbon $(\% \mathrm{C})$ bobot kering biomasnya, sehingga biomas dan produksi neto lamun dapat ditentukan dalam satuan $\mathrm{gC} / \mathrm{m}^{2}$.

\section{Analisis Data}

Analisis terhadap data citra satelit dilakukan dengan mengolah dan mengklasifikasikan data digital satelit melalui proses komputerisasi. Hubungan antara nilai DN (Digital Number) pada band tertentu yang ada pada citra satelit Aster dengan kandugan karbon di lapangan dapat dianalisis dengan uji regresi. Uji regresi merupakan metode matematis yang dapat digunakan ubtuk mengetahui pola hubungan antar variabel dan membuat persamaan estimasi dari variabel tersebut (Sudjana, 1992 dalam Ariyanto, 2011).

Hasil uji regresi akan diperoleh persamaan regresi yang menggambarkan hubungan antara hasil data interpretasi dengan data lapangan. Nilai koefisien determinasi $\left(\mathrm{R}^{2}\right)$ dapat digunakan untuk mengetahui seberapa besar hasil interpolasi dalam menentukan nilai data di lapangan. Nilai ini berkisar antara $0-1$ (dalam arah positif negative), dimana semakin mendekati 0 berarti tidak berpengaruh, sedangkan semakin mendekati 1 artinya berpengaruh sangat kuat. Nilai negatif berarti menunjukkan adanya hubungan yang berbanding terbalik antar variabel. Selain nilai $\mathrm{R}^{2}$, nilai koefisien korelasi (r) yang diturunkan dari nilai $\mathrm{R}^{2}$ juga dapat digunakan untuk mengetahui kekuatan hubungan antar variabel yang diujikan. Nilainya berkisar $0-1$, dengan 0 yang berarti tidak ada hubungan dan 1 memiliki hubungan yang sangat kuat (Sudjana, 1992 dalam Ariyanto, 2011). Sugiyono (2008) dalam Ariyanto (2011) menyatakan bahwa untuk memudahkan melakukan interpretasi kekuatan hubungan antara dua variabel dengan kriteria sebagai berikut:
a. Jika $0-0,199$ : Korelasi sangat rendah
b. Jika 0,20-0,399 : Korelasi Rendah
c. Jika 0,40-0,599: Korelasi Sedang
d. Jika 0,60-0,799 : Korelasi Kuat
e. Jika 0,80-1,000 : Korelasi Sangat Kuat

\section{HASIL DAN PEMBAHASAN}

Hasil

\section{Kandungan Karbon Lamun (Enhalus acoroides)}

Berdasarkan hasil penelitian biomassa karbon lamun (Enhalus acoroides) di pantai sebelah barat Pulau Kemujan Taman Nasional Karimunjawa nilai kandungan karbon total masing-masing stasiun tersaji pada Gambar 1 .

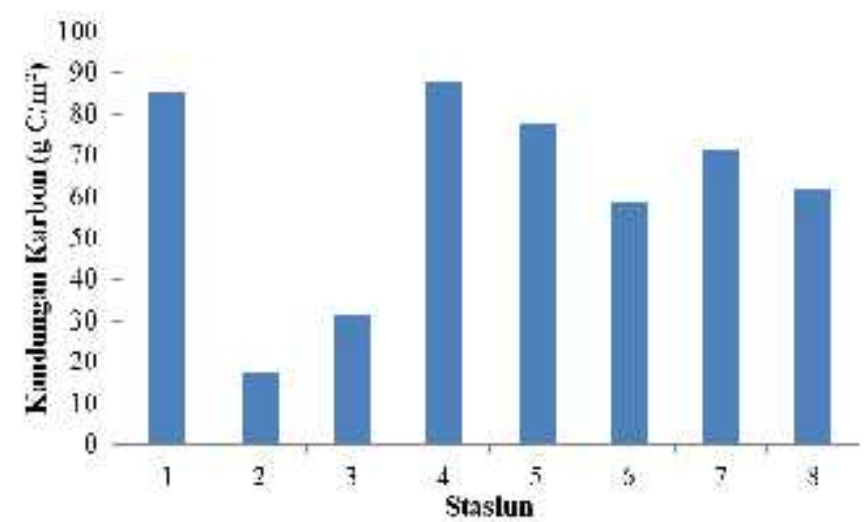

Gambar 1. Diagram Balok Kandungan Karbon Total Lamun (Enhalus acoroides) setiap Stasiun

\footnotetext{
(C) Copyright by Management of Aquatic Resources (MAQUARES)
} 
Berdasarkan hasil yang di peroleh dari penelitian menunjukkan bahwa kandungan karbon total meliputi bagian daun, rhizome, dan akar pada setiap stasiun. Nilai kandungan karbon total tertinggi terdapat pada stasiun 4 yaitu sebesar $88,1029 \mathrm{~g} \mathrm{C} / \mathrm{m}^{2}$, sedangkan nilai yang terendah terdapat pada stasiun 2 yaitu sebesar $17,77 \mathrm{~g}$ $\mathrm{C} / \mathrm{m}^{2}$. Kandungan karbon lamun terbagi menjadi dua yaitu kandungan karbon bagian atas permukaan meliputi daun dan kandungan karbon bagian bawah permukaan meliputi rhizome dan akar untuk lebih jelasnya bisa dilihat pada Gambar 2.

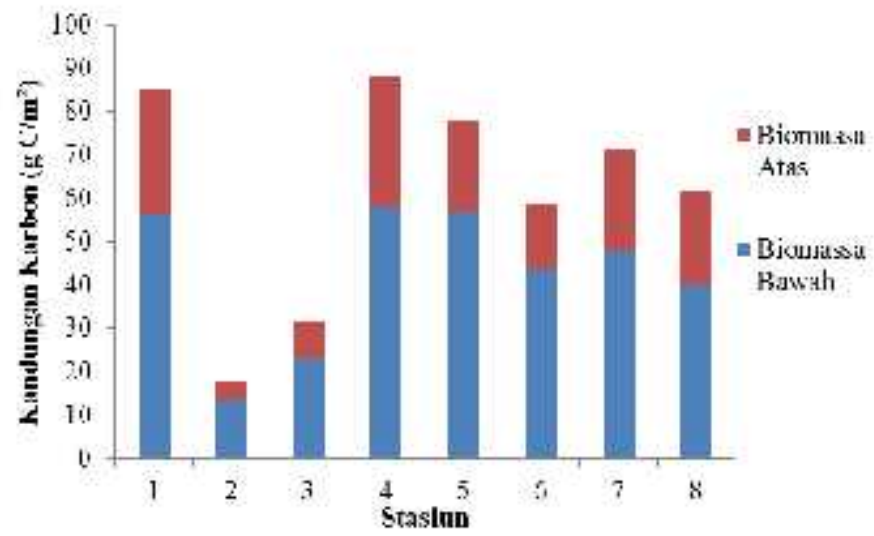

Gambar 2. Diagram Balok Kandungan Karbon Lamun Bagian atas dan Bawah

Hasil yang didapat dari pengukuran kandungan karbon lapangan berdasarkan bagian atas permukaan dan bagian bawah permukaan menunjukkan bahwa di semua stasiun penelitian nilai kandungan karbon bagian bawah permukaan yang meliputi rhizome dan akar memiliki nilai kandungan karbon yang lebih tinggi berkisar antara 13,396 - 57,7569 $\mathrm{g} \mathrm{C} / \mathrm{m}^{2}$ dibandingkan dengan kandungan karbon bagian atas permukaan yang meliputi daun berkisar antara 4,374 - 30,346 $\mathrm{g} \mathrm{C} / \mathrm{m}^{2}$. Kandungan karbon bagian bawah yang memiliki nilai tertinggi berada di stasiun 4 yaitu sebesar $57,5769 \mathrm{~g} \mathrm{C} / \mathrm{m}^{2}$ dan nilai terendah terdapat pada stasiun 2 yaitu sebesar $13,396 \mathrm{~g} \mathrm{C} / \mathrm{m}^{2}$, sedangkan nilai kandungan karbon bagian atas yang tertinggi terdapat pada stasiun 4 yaitu sebesar $30,346 \mathrm{~g} \mathrm{C} / \mathrm{m}^{2}$ dan nilai terndah terdapat pada stasiun 2 yaitu sebesar $4,374 \mathrm{~g} \mathrm{C} / \mathrm{m}^{2}$.

Nilai kandungan karbon bagian bawah permukaan sangat dipengaruhi oleh nilai kandungan karbon dari bagian rhizome, dikarenakan di seluruh stasiun penelitian nilai kandungan karbon bagian rhizome selalu yang tertinggi berkisar antara $12,498-55,967 \mathrm{~g} \mathrm{C} / \mathrm{m}^{2}$, nilai tertinggi terdapat pada stasiun 1 sebesar $55,967 \mathrm{gC} / \mathrm{m}^{2}$ dan terendah pada stasiun 2 sebesar 12,498 gC/m ${ }^{2}$ meskipun nilai kandungan karbon bagian bawah permukaan dipengaruhi oleh nilai kandungan karbon akar yang berkisar antara $0,475-27,147 \mathrm{gC} / \mathrm{m}^{2}$ dengan nilai tertinggi terdapat pada stasiun 5 sebesar $27,147 \mathrm{gC} / \mathrm{m}^{2}$ dan terendah pada stasiun 1 sebesar $0,475 \mathrm{gC} / \mathrm{m}^{2}$ sedangkan kandungan karbon daun berkisar antara 4,374 - 30,346 gC/m $\mathrm{m}^{2}$ dengan nilai tertinggi terdapat pada stasiun 4 sebesar 30,346 $\mathrm{gC} / \mathrm{m}^{2}$ dan terendah pada stasiun 2 sebesar $4,374 \mathrm{gC} / \mathrm{m}^{2}$ untuk lebih jelasnya bisa dilihat pada Gambar 3.

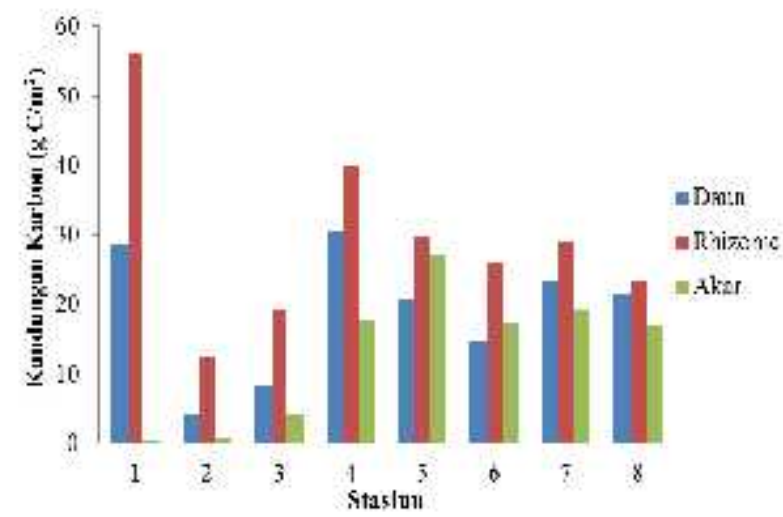

Gambar 3. Diagram Balok Kandungan Karbon Lamun (Daun, Rhizome, dan Akar) pada setiap Stasiun

\section{Sebaran Kandungan Karbon Hasil Pemodelan Algoritma Citra Satelit ASTER}

Pengolahan data dalam penelitian menggunakan citra satelit ASTER dengan melakukan suatu pemodelan algoritma. Data yang digunakan adalah DN (Digital Number) citra satelit ASTER dengan nilai hasil pengukuran kandungan biomassa karbon di lapangan. Berdasarkan pengolahan data, dilakukan berbagai ujicoba kombinasi nilai DN (Digital Number) untuk Band1, Band2, Band3, Band1/Band2, Band1/Band3, Band2/Band3,

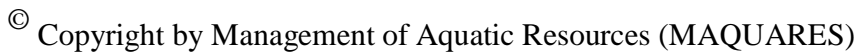


Band2/Band1, Band3/Band1, dan Band3/Band2 dengan nilai hasil pengukuran kandungan biomassa karbon di lapangan. Variabel dengan nilai korelasi tertinggi akan digunakan dalam persamaan regresi untuk mengetahui sebaran kandungan biomassa karbon lamun (Enhalus acoroides). Proses pemodelan algoritma dengan regresi linier. Persamaan regresi didapat dari hubungan antara nilai Band1/Band3 citra ASTER dengan nilai kandungan karbon lamun (Enhalus acoroides). Algoritma yang didapat yaitu y $=77.719 \times(\mathrm{b} 1 / \mathrm{b} 3)-49.881$ dengan nilai $\mathrm{r}=$ 0.975. Berdasarkan nilai $\mathrm{r}$ yang didapat mengindikasikan bahwa ada hubungan yang erat antara DN (Digital Number) citra satelit dan nilai kandungan karbon lamun di lapangan, bisa dilihat pada Gambar 4.

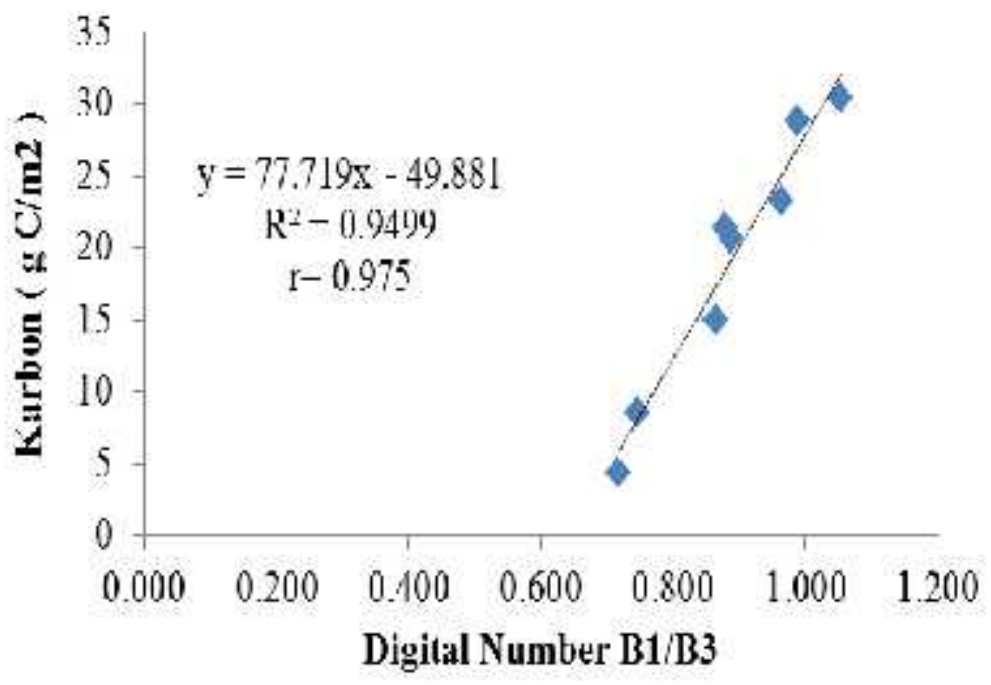

Gambar 4. Grafik Hubungan antara Band1/Band3 Citra Aster dengan Kandungan Karbon Lamun (Enhalus acoroides)

Peta sebaran kandungan karbon lamun menunjukkan bahwa distribusi kandungan karbon tidak merata. Sebaran kandungan karbon lamun (Enhalus acoroides) pada beberapa sampel dari masing-masing stasiun di sebelah barat Pulau Kemujan Taman Nasional Karimunjawa bisa dilihat pada Gambar 5.

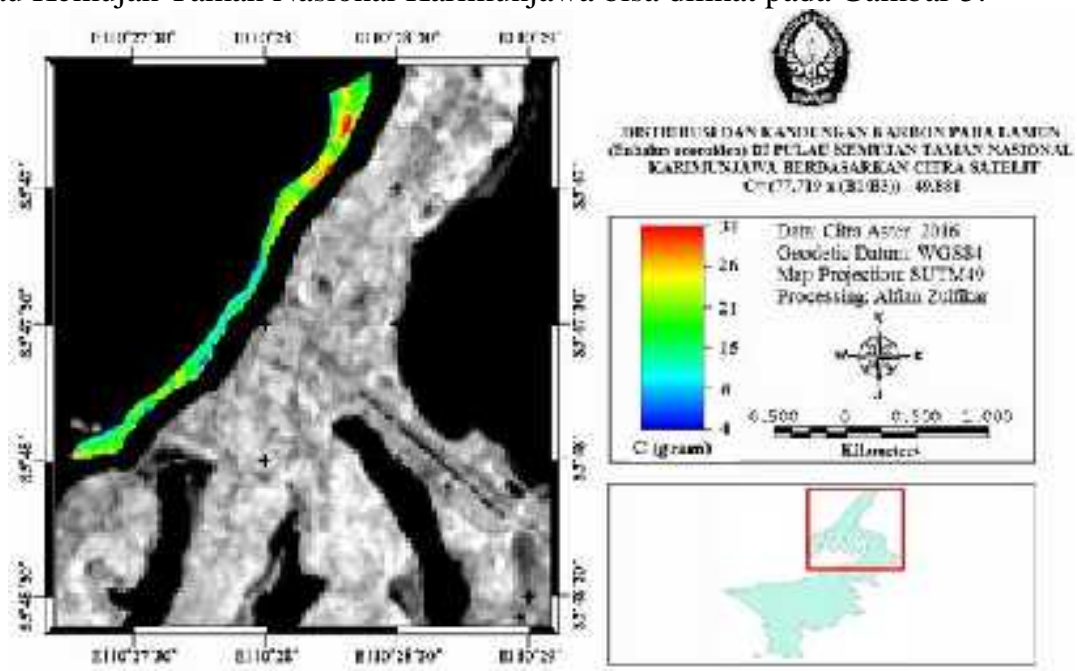

\section{Pembahasan}

Gambar 5. Peta Sebaran Kandungan Karbon Lamun (Enhalus acoroides)

\section{Kandungan karbon lamun (Enhalus acoroides)}

Pada penelitian ini dilakukan perhitungan biomassa dan kandungan karbon pada lamun (Enhalus acoroides) berdasarkan biomassa atas meliputi daun dan biomassa bawah meliputi rhizome dan akar. Berdasarkan hasil biomassa lamun perbagian menunjukan bahwa biomassa lamun tidak selalu berbanding lurus dengan nilai kandungan karbon perbagian lamun tetapi memiliki kecenderungan seperti itu. Pada penelitian ini dilakukan perhitungan kandungan karbon pada biomassa atas permukaan (daun) dan biomassa bawah permukaan (rhizome dan akar).

Hasil penelitian menunjukkan bahwa nilai kandungan karbon perbagian terendah terdapat pada bagian akar yaitu berkisar antara $0,475-27,147 \mathrm{gC} / \mathrm{m}^{2}$, sedangkan urutan kedua nilai kandungan karbon terdapat pada bagian daun yaitu berkisar antara 4,374 - 30,346 $\mathrm{gC} / \mathrm{m}^{2}$ dan nilai kandungan karbon perbagian tertinggi berasal 
dari bagian rhizome yaitu berkisar antara $12,498-55,967 \mathrm{gC} / \mathrm{m}^{2}$. Hal tersebut sama dengan hasil penelitian dari Kiswara (2010) di Pulau Pari Teluk Jakarta dimana hasil kandungan karbon tertinggi terdapat pada bagian rhizome lamun Enhalus acoroides tetapi nilai kandungan karbon jauh lebih tinggi dibandingkan dengan hasil penelitian ini yaitu berkisar antara $12,42-284,91 \mathrm{gC} / \mathrm{m}^{2}$.

Berdasarkan hasil penelitian ini menunjukkan kandungan karbon pada bagian bawah permukaan (below ground) lebih besar dibandingkan dengan bagian atas permukaan (above ground) lamun. Kandungan biomassa bagian atas $(a b g)$ yang terdiri dari daun berkisar antara 4,374 - 30,346 gC/m $\mathrm{m}^{2}$ dengan nilai rata-rata kandungan karbon sebesar $19,0508 \mathrm{gC} / \mathrm{m}^{2}$. Sementara kandungan biomassa bagian bawah permukaan (blg) yang terdiri dari rhizome dan akar berkisar antara 13,396 - 57,7569 $\mathrm{gC} / \mathrm{m}^{2}$ dengan nilai rata-rata sebesar 42,4598 $\mathrm{gC} / \mathrm{m}^{2}$. Sedangkan rata-rata kandungan karbon total penelitian ini sebsesar $61,5107 \mathrm{gC} / \mathrm{m}^{2}$ dengan kisaran 17,77 $88,1029 \mathrm{gC} / \mathrm{m}^{2}$. Hasil yang didapat penelitian ini lebih tinggi dengan hasil penelitian di Pantai Sanur Bali dengan nilai rata-rata sebesar 20,05 $\mathrm{gC} / \mathrm{m}^{2}$ dengan kisaran 4,82-46,89 gC/m², meskipun dalam penelitian Graha, (2015) tidak hanya satu jenis lamun yang diteliti.

Hasil yang di dapatkan penelitian ini lebih rendah baik kandungan karbon bagian atas maupun bawah permukaan bila dibandingkan dengan hasil yang di dapatkan oleh Supriadi et al., (2012) yang dilakukan di Pulau Baranglompo Makassar yaitu rata-rata sebesar $27,831 \mathrm{gC} / \mathrm{m}^{2}$ untuk kandungan karbon bagian atas $(a b g)$ dan rata-rata sebesar 108,029 $\mathrm{gC} / \mathrm{m}^{2}$ untuk kandungan karbon bagian bawah $(b l g)$. Simpanan karbon di bawah substrat $E$. acoroides yang tinggi disebabkan oleh ukuran rhizoma dan akar yang besar, disamping penetrasi akar yang bisa mencapai $40 \mathrm{~cm}$. Salah satu fungsi tingginya penyimpanan biomassa di bawah substrat adalah memperkuat penancapan lamun (Supriadi et al., 2012).

Hasil kandungan karbon dari penelitian juga lebih rendah dibandingkan dengan kandungan karbon di Pulau Pari Teluk Jakarta pada bagian atas permukaan ( $a b g$ ) rata-rata sebesar 40,2 $\mathrm{gC} / \mathrm{m}^{2}$,sedangkan bagian bawah permukaan (blg) lebih tinggi yaitu rata-rata sebesar $41,5 \mathrm{gC} / \mathrm{m}^{2}$ berdasarkan penelitian yang dilakukan oleh Rahmawati (2011). Berdasarkan penelitian yang dilakukan oleh Rustam, et al., (2013) di Tanjung Lesung Banten kandungan karbon total yang didapat sebesar $35,425 \mathrm{gC} / \mathrm{m}^{2}$ hasil ini lebih rendah dibandingkan dengan penelitian ini. Hasil yang didapat penelitian ini lebih tinggi baik kandungan dibawah substrat (blg) maupun diatas substrat $(a b g)$ dibandingkan dengan hasil di Pantai Sanur Bali dengan nilai tertinggi berkisar antara 1,62 $29,54 \mathrm{gC} / \mathrm{m}^{2}$ untuk kandungan karbon dibawah substrat (blg) sedangkan untuk kandungan karbon atas permukaan ( $a b g$ ) tertinggi berkisar antara 3,21 - 18,10 3,77 g C/m². Meskipun dalam penelitian Graha (2015), tidak hanya satu jenis lamun (Enhalus acoroides) saja yang diteliti kandungan karbonnya tetapi jenis-jenis lamun lainnya yang hidup di tempat tersebut.

\section{Sebaran kandungan karbon}

Berdasarkan hasil penelitian di pantai sebelah barat Pulau Kemujan Taman Nasional Karimunjawa, dilakukan analisis biomassa karbon menggunakan pemodelan citra satelit ASTER. Analisis yang dilakukan dengan membuat regresi hubungan antara kandungan karbon di lapangan dan nilai Digital Number (DN) citra. Persamaan yang didapat dari koefisien korelasi (r) tertinggi akan digunakan dalam analisis data citra satelit untuk mengetahui sebaran kandungan karbon lamun jenis Enhalus acoroides yang telah diketahui kandungan karbon lapangannya. Berdasarkan hasil regresi, menunjukan bahwa kombinasi Band yaitu Band1/Band3 memiliki koefisien korelasi tertinggi terhadap terhadap hasil pengukuran karbon di lapangan, sedangkan untuk Band1/Band2, Band1, Band2, Band3, Band2/Band3, Band2/Band1, Band3/Band1, dan Band3/Band2 menunjukan koefisien korelasi yang rendah. Menurut nilai koefisien korelasi yang tinggi, kombinasi Band1 memiliki hubungan yang erat dan dipengaruhi oleh nilai digital number yang didapat dari setiap stasiun yang diambil sampel lamun. Penggunaan Band1/Band3 di dasarkan atas spektral spektrum cahaya tampak dari gabungan band tersebut, dalam hal ini objek vegetasi dipengaruhi oleh pigmen hijau daun yaitu klorofil.

Salah satu data yang diperoleh dari penginderaan jauh adalah karakteristik reflektansi, karakteristik spektral. Karena karakteristik spektral tergantung pada karakteristik objek (Roderick et al., 2000 dalam Ulumuddin et al., 2005), maka Ustin et al., (1999) dalam Ulumuddin et al., (2005) mengkaji asosiasi ini, misalnya dengan mengkaji asosiasi karakteristik spektral dengan karakteristik biofisik (luas dan distribusi daun) dan fisiologis tumbuhan (kandungan air, selulosa dan senyawa karbon lain). Dimana molekul-molekul pigmen hijau yang terdapat pada daun tersebut menyerap panjang gelombang cahaya pada daerah tampak cahaya. Daerah tersebut memiliki rentang spektrum antara $380-700 \mathrm{~nm}$. Cahaya tampak terbagi atas cahaya merah (610 - $700 \mathrm{~nm})$, hijau kuning $(510-600 \mathrm{~nm})$, dan biru $(410-500 \mathrm{~nm})$, dan violet (Graha, 2015). Hal ini menunjukkan bahwa kombinasi Band1/Band3 citra ASTER merupakan band yang sesuai untuk analisis padang lamun dilihat dari panjang gelombangnya. Band 1 adalah band hijau dan band 3 adalah band merah. Menurut Ambarwulan dan Widiatmaka (2002), band 1 dan band 3 merupakan band yang termasuk kedalam geombang tampak mata dan infra-merah dekat (visible and near infrared radiometer-VNIR).

Distribusi kandungan karbon di Pulau Kemujan menunjukkan pola persebaran yang tidak merata. Banyak faktor yang bisa mempengaruhi sehingga hal itu bisa terjadi antara lain adanya kegiatan masyrakat di dermaga, kegiatan budidaya rumput laut ataupun kegiatan pariwisata yang ada di Pulau Kemujan. Hal ini sesuai dengan

\footnotetext{
${ }^{\circ}$ Copyright by Management of Aquatic Resources (MAQUARES)
} 
penelitian yang dilakukan oleh Vatria (2010), di Indramayu menunjukkan bahwa salah satu faktor yang mempengaruhi terjadinya kerukasan ekosistem pantai yaitu pencemaran. Pencemaran di pesisir umumnya berasal dari kegiatan manusia yang berada di sekitarnya seperti membuang sampah sembarangan, limbah rumah tangga ataupun kegiatan pariwisata dan transportasi air. Sedangkan menurut Amri et al., (2011), dampak dari adanya kegiatan manusia terhadap kerusakan padang lamun di Barranglompo Makassar dilihat dari parameter kualitas air yang diteliti. Kekeruhan dan padatan tersuspensi total merupakan parameter yang memiliki pengaruh kuat ditimbulkan langsung dari adanya kegiatan manusia seperti persinggahan perahu nelayan dan pengambilan pasir yang diperkirakan akan menimbulkan kerusakan terhadap padang lamun.

Menurut hasil penelitian Kiswara (1994), yang dilakukan di Teluk Banten menunjukkan bahwa padang lamun di Teluk Banten mengalami kerusakan karena adanya kegiatan perataan bukit, reklamasi/pengurugan pantai untuk perluasan tapak kawasan industri dan penggalian batu untuk bahan pembangunan lapangan terbang cengkareng serta pembuatan pelabuhan. Pengaruh langsung dari adanya kegiatan tersebut yaitu rusak dan hilangnya padang lamun yang berada di Teluk Banten mencapai 50 ha atau sekitar 35\% dari seluruh luas padang lamun yang ada. Sedangkan perngaruh tidak langsung dari kegiatan reklamasi tersebut adalah terhadap sumberdaya perikanan yang berupa penurunan jumlah jenis, marga dan individu jenis-jenis ikan yang berasosiasi dengan padang lamun.

\section{KESIMPULAN}

Kesimpulan yang dapat diambil dari hasil penelitian yang dilakukan yaitu distribusi biomassa dan kandungan karbon lamun (Enhalus acoroides) di Pulau Kemujan Taman Nasional Karimunjawa menyebar tidak merata, hal tersebut menunjukkan adanya pengaruh dari kegiatan manusia terhadap fungsi lamun sebagai penyerap karbon. Adapun kandungan karbon bagian atas permukaan (daun) sebesar 152,407 gC/m² dan bagian bawah permukaan (rhizome dan akar) sebesar 339,678 gC/m².

\section{UCAPAN TERIMAKASIH}

Terimakasih penulis ucapkan kepada tim penguji dan panitia ujian akhir program Dr. Ir. Djuwito, MS, Dr. Ir. Abdul Ghofar, M.Sc, Ir. Anhar Solichin, M.Si, Dr. Ir. Pujiono W. Purnomo, MS dan Churun Ain, S.Pi, M.Si yang telah memberikan masukan, kritik dan saran bagi penulis dalam penyusunan laporan, Balai Taman Nasional Karimunjawa atas ijin dan pendampingan selama penelitian di lapangan, serta semua pihak yang telah membantu dan memberikan dukungan sehingga terselesaikannya tugas akhir program Manajemen Sumberdaya Perairan.

\section{DAFTAR PUSTAKA}

Ambarwulan, W. dan Widiatmaka. 2002. Tinjauan Penggunaan Citra Aster untuk Studi Sumberdaya Alam. Majalah Ilmiah Globe., 4(1): 37 - 46.

Amri, K., D. Setiadi., I. Qayim., dan D. Djokosetiyanto. 2011. Dampak Aktivitas Antropogenik Terhadap Kualitas Perairan Habitat Padang Lamun di Kepulauan Spermonde Sulawesi Selatan. Fakultas Perikanan dan Ilmu Kelautan. Universitas Hasanuddin. [Skripsi].

Ariyanto, D. 2011. Aplikasi Penginderaan Jarak Jauh untuk Analisis Hubungan Biomassa Karbon Hutan Mangrove dengan Kelimpahan Ikan di Desa Bedono Demak. Program Pascasarjana Universitas Diponegoro. Semarang. [Tesis].

Brower, J.E., Zar J.H. and Ende C.N.V. 1989. Field and Laboratory method for general ecology fourth edition. McGraw-Hill Publication. Boston, USA. Xi+237p.

BTNKJ (Balai Taman Nasional Karimunjawa). 2012. Zonasi Taman Nasional Karimunjawa Tahun 2012. Balai Taman Nasional Karimunjawa-Dirjen Perlindungan Hutan dan Konservasi Alam-Departemen Kehutanan Semarang.

Chen, C.F., V.K. Lau., N.B.Chang., N.T.Son., P.H.S. Tong and S.H. Chiang. 2016. Multi-Temporal Change Detection of Seagrass Beds Using Integrated Landsat TM/ETM + /OLI Imageries in Cam Ranh Bay Vietnam. Biological informatics., 35(1): $43-54$.

Graha, Y.I. 2015. Simpanan Karbon Padang Lamun di Kawasan Sanur Kota Denpasar. Magister Ilmu Lingkungan Universitas Udayana Bali. [Tesis].

Kiswara, W. 1994. Dampak Perluasan Kawasan Industri Terhadap Penurunan Luas Padang Lamun di Teluk Banten Jawa Barat. Pusat Penelitian Oseanografi LIPI. Seminar Nasional Jawa Barat. Cengkareng, hlm. 1- 11 (abstrak).

2010. Studi Pendahuluan: Potensi Padang Lamun sebagai Karbon Rosot dan Penyerap Karbon di Pulau Pari, Teluk Jakarta. Pusat Penelitian Oseanografi LIPI. Jurnal Oseanologi dan Limnologi.,36(3): $361-376$. 
McKenzie, L.J. 2003. Guidelines For The Rapid Assessment Of Seagrass Habitats In The Western Pacific. QFS., NFC.,Caims. 43p.

Rustam, A., T.L. Kepel., R.N. Afiati., H.L. Salim., M. Astrid., A. Daulat., P. Mangindaan., N. Sudirman., Y. Puspitaningsih R., D. Devi Dan A. Hutahaean. 2013. Peran Lamun Sebagai Blue Carbon dalam Mitigasi Perubahan Iklim, Studi Kasus Tanjung Lesung, Banten. Pusat dan Penelitian dan Pengembangan Sumberdaya Pesisir dan Laut, Kementrian Kelautan dan Perikanan.

Sakaruddin, M.I. 2011. Komposisi Jenis, Kerapatan, Persen Penutupan dan Luas Penutupan Lamun di Perairan Pulau Panjang Tahun 1990 - 2010. Fakultas Perikanan dan Ilmu Kelautan. Institut Pertanian Bogor. Bogor. [Skripsi].

Sarah., F. Lestari, dan A. Zulfikar. 2015. Analisis Biomassa Lamun di Desa Pengudang Kecamatan Teluk Sebong Kabupaten Bintan Provinsi Kepulauan Riau. Fakultas Perikanan dan Ilmu Kelautan. Universitas Maritim Raja Ali Haji. [Skripsi]

Supriadi., R.F. Kaswadji., D.G. Bengen dan M. Hutomo. 2012. Potensi Penyimpanan Karbon Lamun Enhalus acoroides di Pulau Baranglompo Makassar. Universitas Hasanuddin Makassar. Jurnal Ilmu Kelautan., 19(1): $1-10$.

Sutaryo, D. 2009. Perhitungan Biomassa (Sebuah Pengantar untuk Studi Karbon dan Perdagangan Karbon). Wetland International Indonesia Programme. Bogor.

Ulumuddin, Y.I., E. Sulistyawati., D.M. Hakim., dan A.B. Harto. 2005. Korelasi Stok Karbon dengan Karkteristik Spektral Citra Landsat: Studi Kasus Gunung Papandayan. Institut Teknologi Sepuluh Nopember. Surabaya.

Vatria, B. 2010. Berbagai Kegiatan Manusia yang Dapat Menyebabkan Terjadinya Degradasi Ekosistem Pantai Serta Dampak yang Ditimbulkannya. Jurnal Belian., 9(1): $47-54$.

Wicaksono, S.G., Widianingsih. dan S.T. Hartati. 2012. Struktur Vegetasi dan Kerapatan Jenis Lamun di Perairan Kepulauan Karimunjawa Kabupaten Jepara. Journal Of Marine Research., 1(2): 1 - 7. 